\title{
Часть II
}

\section{Проблемы трансляции и трансформации буддизма \\ в историческом и современном аспектах}

DOI 10.31554/978-5-7925-0530-8-2018-132-148

\section{РАСПРОСТРАНЕНИЕ БУДДИЗМА МАХАЯНЫ В СОЦИОКУЛЬТУРНОМ ПРОСТРАНСТВЕ США}

Аякова Жаргал Аюшиевна кандидат философских наук

Отдел международных связей

Бурятской государственной сельскохозяйственной академии.

E-mail: azhargal@yandex.ru

В настоящее время буддизм в Северной Америке представляет собой значительное явление. Американские буддисты представлены как обширными азиатскими диаспорами, так и новообращенными последователями. Сегодня буддизм в Северной Америке представлен практически всеми школами и направлениями, но наиболее востребованным оказался буддизм Махаяны. Высокая адаптивная способность буддизма Махаяны к новым социокультурным реалиям Америки еще раз показала его жизнестойкость и жизнеспособность в современном глобализирующемся мире. В США авторитет Его Святейшества Далай-ламы XIV продолжает расти.

Ключевые слова: Северная Америка, буддизм Махаяны, Его Святейшество Далай-лама XIV, геше Вангьял, медитация, «демократизация» буддизма, сострадание.

\section{SOCIO-CULTURAL ASPECT OF MAHAYANA BUDDHISM IN THE USA}

\author{
Zhargal Aiakova \\ CSc in Philosophy \\ International Connections Office \\ Buryat State Academy of Agriculture, Ulan-Ude, Russia \\ E-mail: azhargal@yandex.ru
}

Nowadays Buddhism in the North America is presented by different traditions, schools and communities. American Buddhists include many Asian Americans, as well as a large number of converts of other ethnicities, and now their children and even grandchildren. Nowadays Mahayana Buddhism is very popular amongst the Americans due to its philosophical heritage and the authority of His Holiness the $14^{\text {th }}$ Dalai Lama. Mahayana Buddhism has been adapting to American conditions displaying its spiritual and intellectual potential in the contemporary global world. 
Keywords: North America, Mahayana Buddhism, the $14^{\text {th }}$ Dalai Lama, Geshe Wangyal, meditation, democratization of Buddhism, compassion.

Буддизм Махаяны как феномен культуры Востока, нетрадиционных ценностей и безграничных возможностей духовноинтеллектуального исследования в последние десятилетия вызывает глубокий интерес научных кругов и культурной элиты Америки.

Наряду с появлением буддизма как маргинальной религии китайских и японских иммигрантов на западном побережье США, приехавших в качестве рабочих в период Золотой лихорадки в середине XIX в., несколько американских интеллектуалов-теософов в Нью-Йорке начинают проявлять интерес к буддизму. Самыми известными из них были Елена Петровна Блаватская (русская дворянка, гражданка США) (Helena Blavatsky) и Генри Стил Олкотт (Henry Steel Olkott). Деятельность созданного ими Теософского общества во второй половине XIX в. значительным образом способствовала распространению буддизма Махаяны в США. Надо сказать, что до этого были попытки описания буддийского мировоззрения, например, американскими трансценденталистами и поборниками нравственной философии Р. Эмерсоном, Г. Торо, У. Уитменом. Например, Г. Торо публикует отрывок из «Сутры Лотоса» в американском журнале Dial, обозначая проявление интереса американской публики к буддизму. Однако их попытки остались на уровне элитарного представления, из-за чего появился термин «элитарный буддизм». Теософы же начали с того, что выступили против общественного мнения об азиатах «как о невежественных дикарях», а об их религии «как о шутовском наряде, скроенном из лоскутов суеверий» [Blavatsky, 1989]. В 1880 г. Е. Блаватская и Г. Олкотт обратились в буддизм, приняв Прибежище в Трех Драгоценностях (Будда, Дхарма, Сангха) и взяв пять обетов (панчашила) у буддийского монаха на Цейлоне (Шри Ланка). В основу их исследовательской деятельности легли буддийские тексты и манускрипты, особенно касающиеся учения Махаяны, с использованием специфической терминологии из санскрита, пали, тибетского, китайского и монгольского языков [Richard, 1999, p. 263]. Убеждённые в том, что практически все религии произошли от некоего единого источника, они пыталась найти в духовной культуре Востока те «зёрна истины», которые позднее были только развиты в 
других цивилизациях. Книга Е. Блаватской «Голос безмолвия» (Тhe Voice of the Silence), написанная на основе древнейших тибетских манускриптов, до сих пор вызывает огромный интерес читателей. Спустя сто лет, в 1989 г., было выпущено юбилейное издание, предисловие для которого написал Его Святейшество Далай-лама XIV. В этом предисловии, озаглавленном «Путь Бодхисаттвы», говорится, что книга Блаватской оказывает сильное влияние на людей, которые искренне ищут и стремятся приобщиться к мудрости и состраданию [Blavatsky, 1989]. А «Буддийский катехизис» (Buddhist Catechism) Олкотта выдержал 44 издания (к 1938 г.), был переведён на 20 языков и стал всемирно используемым учебником.

Несмотря на то, что американское общество было не готово понять мировоззрение Востока, Блаватская и Олкотт продолжали продвигать его религиозно-философские ценности и пропагандировать идею о том, что восточная культура понимает «важность вещей незримых, так как чувства крайне ограниченны» [Крэнстон, эл. ресурс]. Важнейшим вкладом в распространение буддизма в США явилось их участие во Всемирном Парламенте Религий (The World's Parliament of Religions), крупнейшем межрелигиозном форуме XIX века, состоявшимся в Чикаго в 1893 г. Теософы способствовали тому, чтобы на этом форуме впервые выступили буддисты. Таким образом, это событие обозначило официальное появление буддизма на арене американской общественности. На форуме о буддизме впервые рассказали Анагарика Дхармапала (Цейлон), Киндза Хираи, Сойэн Сяки и Дзицудзэн Асидзу (Япония). Надо отметить, что личность Дхармапалы имеет исключительное значение в истории буддизма. Он являлся идеологом и организатором возрождения буддизма в Индии. В своих публичных лекциях выступал за активную позицию буддистов, за распространение ценностей буддизма на благо общества, за преобладание разума над слепой верой. На конференции Дхармапала выступил по трём основным темам. Во-первых, он сказал, что буддизм является религией и философией, вполне согласующимися с современной наукой, так как буддийское учение совместимо с доктриной эволюции. Он изложил буддийскую идею о том, что космос есть последовательный процесс развёртывания в соответствии с законами природы. Во-вторых, Дхармапала заявил, что в этике буддизма значительно больше любви и сострадания, чем 
где бы то ни было. Третьим пунктом его выступлений было утверждение о том, что буддизм - это религия оптимизма и активности, но ни в коем случае не пессимизма и бездеятельности [Richard, 1999, p. 263]. Дхармапала принял решение посвятить жизнь защите и возрождению буддизма и начал работать в буддийской секции Теософского общества, в рамках которого ему удалось пробудить интерес к восстановлению из руин священных мест буддизма в Индии. Так, он инициировал восстановление буддийского центра и строительство монастырского комплекса в Сарнатхе, где состоялась первая проповедь Будды.

Тогда буддизм с трибуны докладчиков показался слишком аскетичным и загадочным для западной публики. В заключительной речи при закрытии Парламента Дж. Г. Бэрроуз заявил:

«Парламент показал, что христианство по-прежнему остаётся великим движителем человечества, что нет учителя, равного Христу, и нет Спасителя, кроме Христа. Представителям Востока не следует истолковывать ту учтивость, с которой их принимали здесь, за готовность американского народа заменить восточной верой свою собственную» [Крэнстон, эл. ресурс].

Некоторые исследователи оценивают теософию Блаватской и Олкотт как одно из крупных современных религиозно-философских направлений Запада. Японский философ и буддолог Дайсэцу Судзуки считал, что «несомненно, г-жа Блаватская каким-то образом была посвящена в более глубокие положения учения Махаяны...» [Suzuki, 1969, p. 13]. Популярность учения Е. П. Блаватской объясняется тем, что оно предлагало религиозно-философское мировоззрение, приспособленное к менталитету западных людей XIX века, пронизанному рационализмом и позитивизмом, а также зарождающимся идеалом «американской мечты» об индивидуальном процветании, прежде всего материальном.

В то время как осуществлялись первые шаги по исследованию буддизма в США, на побережье Калифорнии активно прибывали азиатские иммигранты, принося с собой буддийскую веру, ее символы и атрибуты. Буддисты иммигрировали в Северную Америку в разные исторические моменты и по целому ряду причин. Первые иммигранты из Китая и Японии начали прибывать в Калифорнию и на Гавайи еще в середине 1800-х годов, в основном в качестве 
рабочих-мигрантов для строительства железных дорог, работы в шахтах, на фермах и сахарных плантациях. Однако, только в XX в. начался процесс последовательных волн иммигрантов-беженцев из Китая, Японии, Кореи, Вьетнама, Лаоса, Мьянмы, Шри-Ланки, Камбоджи, Таиланда, Тибета, Непала, переселившихся из-за социально-политических и экономических проблем в их странах. После того, как они прибыли в Америку, многие иммигранты столкнулись с серьезными проблемами, связанными с их адаптацией к новой социальной, культурной и религиозной среде. Большинство из них нашли свое убежище и духовное утешение в своих общинах и возведенных ими небольших буддийских молельных домах, позже буддийских храмах, построенных общими усилиями общины или на средства благотворителей и меценатов. Сегодня буддисты Северной Америки включают американцев, являющихся потомками азиатских иммигрантов (например, китайские и японские американцы, являются пятым, шестым, и даже, седьмым поколением американцев) и иммигрантов, продолжающих прибывать из южно-азиатских стран, а также Монголии и России (Калмыкия и Бурятия). Буддийская иммиграция является постоянным процессом, новые иммигранты прибывают и постепенно вливаются в контекст существующих этнических сообществ и социокультурных реалий Северной Америки.

Первый буддийский храм в Америке был построен в 1853 г. в СанФранциско, а к 1900 г. их количество доходило до четырех сотен, большинство из которых представляли собой joss houses или небольшие молельные дома [Prebish, 1999, p. 159-160]. Китайские буддийские храмы и молельные дома в Америке часто характеризуются смешением элементов буддизма, конфуцианства и даосизма и почти всегда включают буддийский образ Гуаньинь, бодхисатвы сострадания.

В 1882 г. в ответ на массовую иммиграцию китайцев в Америку Конгресс США принял особый закон - Акт об исключении китайцев (Chinese Exclusion Act), просуществовавший до 1965 г. Данный закон запретил любую китайскую иммиграцию и натурализацию уже проживающих в США китайцев. Акт об иммиграционной реформе 1965 г. отменил региональные и этнические квоты, чем вызвал очередную волну китайской иммиграции. Согласно данному закону, приоритет отдавался воссоединению семей и стимулированию 
притока работников высокой квалификации. К 1990 г. китайское население в США достигло 921000 человек [Seager, 1999].

Другая волна азиатских иммигрантов прибыла из Японии во второй половине 1800-х годов. Обосновавшись преимущественно на Гавайях, они занимались сельскохозяйственными работами. Большинство из них были буддистами, относящимися, прежде всего, к школе буддизма Чистой Земли (Дзёдо Синсю), в основе учения которой лежит махаянский культ Будды Амитабхи - одного из пяти Дхьяни-будд в системе Ваджраяны. Одной из самых известных организаций данного толка является «Буддийские Церкви Америки» (Buddhist Churches of America), начавшая свою деятельность в 1870 г. и во многом определившая стиль и образ японского монашества, а также деятельность современных японских буддийских организаций и центров в США. В настоящее время Буддийские Церкви Америки насчитывают около 60 центров и организаций по всей стране. Японские бишопы и служители церкви начали активно заниматься пропагандой учения Дзёдо Синсю, упростив религиозную практику и акцентировав внимание на прозелитическую деятельность. Здесь просматривается влияние евангелических образцов, что послужило поводом для появления такого понятия как «евангелический буддизм», ставшего следствием их тесного взаимодействия с христианскими миссионерами и церквями-комьюнити США. Японские иммигранты не отказывались от помощи христианских церквей, в которой они так нуждались в период социальной и культурной адаптации. К 1900 г. японская иммиграция в США перешагнула численность в 24000 человек [Seager, 1999, р. 53], среди которых многие исповедовали буддизм школы Нитирэн и Дзен.

Корейские иммигранты начали прибывать в США в начале XX в. для работы в сельскохозяйственной сфере страны. Несмотря на то, что большинство прибывших корейцев исповедовали христианство, корейские буддисты начали активно возводить буддийские храмы и проводить регулярные религиозные службы. После корейской войны в начале 1950-х большое количество женщин прибыли в качестве жен и невест американских солдат. В 1988 г. примерно из 150000 корейцев в Лос-Анджелесе только 10-15 \% идентифицировали себя как буддистов. Тем не менее, в конце 1980-х годов на территории США функционировали 67 корейских буддийских храмов с активным 
членством в 25000 человек [Ibid., p. 168]. Самые популярные корейские буддийские храмы находятся в обширном районе Кореятаун, расположенном в центре Лос-Анджелеса. Большинство храмовых служб концентрируется на воскресной службе, состоящей из чтения текстов, церемоний, чантов (мантр) и наставлений. Службы не рассматриваются как обязательная часть, поэтому храмовая служба посетителей, количество которых варьируется от 50 до 100 человек каждое воскресенье, отражает малое количество всех формальных служб. Полные службы в основном проводятся при проведении особых мероприятий и буддийских праздников, например, Дня рождения Будды. Большинство храмов фокусирует свою деятельность на молебнах и декламировании мантр, нежели на медитации, так как последняя не особо привлекает корейских мирян. Другие предлагают членам общины ряд социально-религиозных услуг, которые традиционно востребованы перед важными событиями, такими как создание семьи, посещение больных в медицинских учреждениях, наставление молодежи. Многие старшие монахи не говорят на английском языке, что не позволяет им активно взаимодействовать с молодым поколением корейцев, выросших в Америке. Сангха часто испытывает финансовые затруднения, поэтому монахи вынуждены работать за пределами храма, что часто не находит одобрения у части мирян. Некоторые из монахов, оказавшись в Америке, оставили свою монашескую деятельность в поисках работы, - явление достаточно распространенное в истории азиатской монашеской иммиграции. Наряду с чувством отчуждения, преследующего буддийских иммигрантов в процессе адаптации к американской жизни, им приходится сталкиваться с критикой и попытками обращения со стороны корейских христиан. Иногда корейским буддистам, занятым в бизнессфере, приходится не афишировать на публике свою религиозную принадлежность и не посещать буддийские храмы, так как это может стать препятствием в сотрудничестве с бизнес партнерами или боссами, являющимися корейскими христианами. Старшее поколение корейских буддистов особенно ценит строгую религиозную дисциплину и комфортные условия в буддийских храмах. Часто при храмах работают книжные отделы, предлагающие богатый выбор буддийской литературы на корейском и английском языках. Корейские буддисты считают, что Учение Будды есть не только 
источник внутренней трансформации, но и интеллектуальный фундамент их культуры.

Вьетнамские храмы отражают опыт иммигрантов, прибывших в США после войны во Вьетнаме и принятия Закона об Индокитайской миграции и поддержке беженцев в 1975 г. Многим пришлось жить в лагерях беженцев в Гонконге, Лаосе, Малайзии, Таиланде и на Филиппинах до получения всех необходимых документов, которые позволили бы им иммигрировать в США. Многие из них служили в Южной армии Вьетнама и были так или иначе связаны с американскими оккупационными силами; другие мигрировали, чтобы избежать репрессивных мер политики социалистического режима, который в самом начале предполагал притеснение буддистов в стране. В последующие два десятилетия буддизм вьетнамской традиции в Америке распространялся стремительно и к 1995 г. насчитывалось около 160 вьетнамских буддийских монастырей и центров [Cuong Tu Nguyen, 1998, p. 130]. Основной практикой в буддизме вьетнамской традиции является достижение и накопление заслуг. Целью накопления заслуг является перерождение в Чистой Земле Будды Амитабхи. Вьетнамские буддисты концентрируется на ритуалах и проведении особых праздничных церемоний и мероприятий. Таким образом, одним из основных функций храма является отправление служб и проведение ритуалов, а также оказание религиозных услуг населению. Несмотря на то что буддизм вьетнамцев имеет децентрализованную организационную форму, практика остается в основном унифицированной. Можно изучить практически все об общих характеристиках вьетнамской практики буддизма, посетив любой из вьетнамских храмов в США. Храм осуществляет свою важную социальную роль: он является местом, где сохраняются традиционные культурные ценности, куда вьетнамские дети и молодежь приходят не только для изучения Дхармы, но и для изучения традиций и обычаев своих предков. Вьетнамские буддисты поддерживают храмы путем добровольных пожертвований, а в особых случаях настоятель храма может обратиться за поддержкой к мирянам после учения или службы. Во многих храмах, часто в выходные дни, работают вьетнамские волонтеры, родившиеся и выросшие в США, но свободно владеющие родным языком, что позволяет проводить занятия по изучению вьетнамского языка или 
переводить учение Дхармы специально для детей. Вьетнамское монашество старается поддерживать тесную связь с подрастающим поколением американских вьетнамцев, выросших и получающих образование в американской культурной и лингвистической среде, большинство из которых уже не владеют родным языком. В свою очередь, существует проблема нехватки образованных монахов, свободно владеющих английским языком, обладающих глубокими знаниями буддийской философии и осведомленных в событиях современной жизни. Стоит отметить, что буддизм во вьетнамской традиции пользуется наименьшей популярностью среди евроамериканцев. Основной причиной этого является недостаток какой-либо строго очерченной интеллектуальной традиции и четкой артикулированной философии. Буддийская практика глубоко укоренена во вьетнамскую культуру и практически не обращается к медитативной практике, что особенно привлекало бы евроамериканцев.

Тибетские буддийские иммигранты США стали примером иной модели миграции. Большинство тибетцев иммигрировали в США после бегства из Тибета в Индию или Непал в результате событий 1959 г., когда Его Святейшество Далай-лама XIV был вынужден покинуть Тибет и отправиться в Индию. Учитывая сложившуюся ситуацию в Тибете, при котором межкультурные и религиозные коммуникации приобрели драматический характер, тибетские буддисты нашли живой отклик и поддержку со стороны индийского правительства. Американская общественность также выразила свою поддержку и инициировала различные социально-культурные проекты по содействию тибетским беженцам. Широко известная кампания за свободный Тибет была развернута многими известными американскими общественными, культурными и научными деятелями в целях привлечения внимания к проблемам Тибета и спасения тибетской цивилизации. После 1955 г. в США начали прибывать первые учителя тибетского буддизма, самым известными из которых был Геше Вангьял, основавший Буддийский образовательный центр около Нью-Йорка. Среди учеников Геше Вангьяла были такие ныне известные профессора и ученые как Роберт Турман (Robert Thurman), Джеффри Хопкинс (Jeffrey Hopkins), Кристофер Джордж (Christopher George), Александр Берзин (Alexander Berzin), Дональд Лопес (Donald S. Lopez), Анна Кляйн (Anne Klein), Даниэль Козорт (Daniel Cozort) и 
др. Они изучали тибетский язык, санскрит и обучали английскому языку тибетских лам. С помощью своих американских учеников Геше Вангьял написал свою первую книгу «Двери Освобождения» (Door of Liberation) [Geshe Wangyal, 1995], которая, по мнению Роберта Турмана, до сих пор представляет собой одно из лучших введений в тибетский буддизм для западных читателей. Благодаря усилиям Геше Вангьяла и его американских учеников в 1979 г. состоялся первый визит Его Святейшества Далай-ламы XIV в США, ставший важнейшим событием для буддистов Америки и вызвавший повышенный интерес общественности к духовному лидеру буддистов и буддизму Махаяны в целом. Сегодня приглашения и визиты Его Святейшества в США стали регулярным событием, свидетельствующими об авторитете его как личности и востребованности буддийского учения как для круга его последователей и почитателей, так и для светского круга, интересующегося буддизмом с точки зрения его философии, науки и психологии. Публичные лекции Его Святейшества собирают огромные залы от Нью-Йорка до Сан-Франциско, ведущие университеты США приглашают его для встреч с академическим сообществом и проведения лекций по буддийской философии для студентов. Профессор Дж. Хопкинс говорит:

«Выступления Далай-ламы - яркое свидетельство его мощного интеллекта и способности выразительно и доходчиво излагать свои мысли в сочетании с характерным для него деятельным состраданием. Его речь идет от сердца и исполнена мудрости, почерпнутой из буддийской традиции, которая достигла высочайшего уровня развития в регионе распространения тибетской культуры» [Далайлама XIV, 1981, эл. ресурс].

Проживающие в США тибетцы гордятся своей буддийской идентичностью и принимают активное участие в церемониях, проводимых их духовным лидером Его Святейшеством Далай-ламой и другими признанными и уважаемыми религиозными деятелями. С 2007 г. Его Святейшество Далай-лама XIV является заслуженным профессором (Presidential Distinguished Professor) университета Эмори (Emory University) в Атланте, штат Джорджия. Университет стал платформой для тесного взаимодействия между современной наукой и тибетской формой буддизма, на основе которой была запущена программа под названием «Научная инициатива Эмори - Тибет». 
Целью инициативы является разработка новой дисциплины по научному мировоззрению для буддийских монахов. Президент университета Эмори Джеймс Вагнер сказал по поводу этого сотрудничества: «Присутствие коллеги такой величины, как Далай-лама в нашем сообществе является бесконечным источником вдохновения и ободрения для наших преподавателей, сотрудников и студентов, поскольку мы стремимся реализовать концепцию обучения и сердца и ума на благо всего человечества. Его лекции вносят значительный вклад в достижение стратегических целей университета и объединение крупного научного сообщества для решения актуальных проблем» [The Dalai Lama as Professor, эл ресурс].

Университет тесно сотрудничает с Американской Академией Религии (American Academy of Religion), самой крупной ассоциацией, объединяющей около 10000 общественных и религиозных деятелей, ученых и профессоров со всего мира.

Буддийские общины, отличающиеся по своим этническим, лингвистическим, культурным, экономическим характеристикам, пользуясь социальной помощью от правительства США и Канады, родственников, друзей, церквей и храмов, по-разному поддаются «корректировке» и «американизации». Считая себя верными последователями Учения Будды Шакьямуни, тем не менее, буддийские иммигрантские общины понимают и интерпретируют буддизм поразному, пропуская его через свой собственный культурный опыт. Существующие различия не могут быть недооценены; говоря о буддизме в китайской, корейской или вьетнамской традициях, важно признать, что каждая из этих традиций была сформирована в той или иной этнической или национальной среде, обусловленной различными культурными, образовательными, социально-экономическими и географическими условиями. Стоит отметить, что не все буддийские иммигранты остаются буддистами. Некоторые обращаются в христианство, например, из-за чувства долга или благодарности за помощь, оказанную служителями американских христианских церквей в период переезда и оформления иммиграционных документов. Другие новообращенные, хотя и были проникнуты буддийскими ценностями, такими как, например, сострадание ко всем живым существам, тем не менее, мало знали о буддизме и его философии. 
Азиатским буддистам в США пришлось столкнуться с огромными трудностями при обустройстве своего быта и создании храмов в чужой стране, поначалу часто враждебно настроенном социальном окружении. Буддийское учение о сострадании, терпимости, безграничной любви ко всем живым существам, несомненно, было и остается духовным стержнем и поддержкой для азиатской иммиграции, испытывающей трудности в процессе адаптации и жизнедеятельности в американской среде. Будучи иммигрантамибеженцами, им особенно было тяжело справиться с социальной дезориентацией, последствиями психологических и физических травм, связанными с военно-политическими событиями в их странах. В современных условиях буддизм Махаяны продолжает служить поддержкой для иммигрантских общин в преодолении стрессов и социального дискомфорта и не прекращает быть духовной опорой в поиске смысла жизни в новых условиях.

Сегодня буддизм в США представлен разными школами и направлениями, и, являясь одновременно религией, философией и наукой, воспринят миллионами американцев по всей стране с целью духовного самосовершенствования и поиска путей гармоничного существования и сосуществования с окружающим миром. В настоящее время в США насчитывается от трех до четырех миллионов буддистов [Seager, 1999] (согласно другим данным - от пяти до шести миллионов), из которых подавляющее большинство составляют азиатские американцы и азиатские иммигранты. Евроамериканских (или белых американских) буддистов насчитывается около 800,000 человек [Ibid.]. Деление буддистов на евроамериканцев, американцев азиатского происхождения и азиатских иммигрантов является одной из основных характеристик и отправной точкой для исследования буддизма в Америке. Однако существует мнение, что категория «евроамериканцы» не включает афроамериканских и латиноамериканских буддистов и не учитывает их растущее количество. Между буддистами разных категорий существуют различия в религиозно-философском и культурном планах и в способах выполнения практики буддизма.

На сегодняшний день остается все еще нерешенной проблема определения категории «буддист» в американском обществе. Очевидно, что азиатские американцы и азиатские иммигранты 
являются буддистами, практикующими буддизм как религиозную традицию со всеми присущими ей ритуальными практиками и поклонением буддийскому пантеону и монашеству. Его Святейшество Далай-лама XIV, отвечая на вопрос, что отличает буддистов от не буддистов, говорит: «С точки зрения Прибежища, буддистом является тот, кто принимает Будду, его учение (Дхарму) и духовную общину (Сангху) как свое конечное прибежище. С философской точки зрения буддистом является тот, кто признает четыре принципа, подтверждающих, что учение является буддийским» [Далай-лама $\mathrm{XIV}$, эл. ресурс]. Буддийская практика американских буддистов азиатского происхождения и азиатских иммигрантов заключается в посещении буддийских храмов и молельных домов, начитывании мантр, отправлении религиозных обрядов и соблюдении ритуалов. Они отмечают буддийские праздники, справляют важные личные и семейные события согласно буддийским традициям. Для американцев буддизм Махаяны является, прежде всего, философским учением и источником мудрого отношения к жизни. Американские буддисты посещают публичные лекции и учения Его Святейшества Далай-ламы $\mathrm{XIV}$ и других буддийских учителей, черпают знания и буддийскую мудрость из книжных и других источников, занимаются медитативными практиками в различных дзен-дхарма-сангха центрах, реализуют социально значимые проекты, составляющие суть социально ангажированного буддизма. Слова Стивена Бэчелора (Stephen Batchelor), автора известной в Америке книги «Буддизм без веры», «Вам не нужно быть религиозным человеком, чтобы практиковать Дхарму» стали чрезвычайно популярными, ознаменовав, таким образом, общую тенденцию процесса американизации буддизма [Batchelor, 1997, p. 18].

Бывший буддийский монах, буддист-агностик, как он себя называет, С. Бэчелор обрел широкую популярность в среде евроамериканских буддистов, проповедуя секулярный буддизм и обучая практикам медитации в университетах США. Под его влиянием многие современные западные учителя и их последователи приняли буддизм не как религиозную веру, а как образ жизни, ведущий к обретению духовной свободы, гармоничного мироощущения и личностного роста. 
Сложность категоризации американских буддистов вызывает нескончаемую дискуссию в среде американского научного сообщества. Дж. Нэттьер говорит о необходимости прийти при изучении американского буддизма к однозначному решению вопроса о том, кто может быть включен в категорию «буддист». Вызывает вопрос, достаточно ли просто называть себя буддистом или существуют критерии, такие как вера, ритуальные практики, активное членство в буддийской организации или общине. Хотя эти вопросы возникают при изучении любой религиозной традиции, они особенно остры в случаях с религиями, которые адаптируются и носят относительно немногочисленный характер, а еще меньшее количество людей имеют свой собственный религиозный опыт и знания. Так, в частности, напрашивается вопрос:

«Например, если второкурсник колледжа покупает книги по дзен буддизму Алана Уотса (Alan Watts), читает их, ему нравится то, что он читает, и постепенно он начинает думать о себе, что он буддист хотя не встречался ни с какими другими формами буддизма за пределами печатных текстов - может ли он быть включен в категорию «буддист» при изучении буддизма в Северной Америке?»

Нэттьер предполагает, что многие исследователи и даже большинство буддистов ответили бы на этот вопрос негативно. Но подход олинклюзив позволяет представить картину большего числа «буддистов», чем можно было бы предположить. Что касается подхода эксклюзивности, то связанные с ним критерии веры и ритуальной практики начинают быстро напоминать стандарты ортодоксии, - пишет Нэттьер [Nattier, 1998, p. 184-185].

Томас Твид выносит на обсуждение категорию «симпатизирующие буддизму» (Buddhist sympathizers) или «найтстэнд буддисты» (nightstand Buddhists), для которых издания по буддизму являются настольными книгами. Профессор Твид подчеркивает, что важно учитывать огромное количество американцев, для которых книжные, периодические, видео, аудио-издания по буддизму являются духовноинтеллектуальными источниками и мудрыми руководствами в жизни, и, хотя не занимаются религиозными практиками и не принадлежат ни к каким буддийским организациям, они называют себя «буддистами» [Tweed, 1992, p. 42-43]. Распространение буддийских знаний и ценностей посредством различных информационных и 
издательских систем в Америке вылилось в так называемый публичный буддизм или медиа буддизм. По мере дальнейшего развития информационно-телекоммуникационных систем и возможности их использования привели к появлению таких понятий, как hard Buddhism и soft Buddhism по аналогии жестких и мягких носителей информации, подразумевающих степень вовлеченности индивида в буддийский дискурс. Существует большое количество американских сайтов, посвященных буддизму и представляющих возможность для виртуального учения и практики. Благодаря онлайн буддизму стали популярными такие термины, как кибер буддизм, кибер сангха, кибер храм, кибер алтарь. Американские буддийские сайты обычно информационно насыщенны и являются местом соединения традиционных буддийских верований и новых технологий, задача которых - сделать учение Будды доступным. Лекции Его Святейшества Далай-ламы XIV и других буддийских учителей транслируются в интернете в режимах онлайн и офлайн. Стоит отметить, что Его Святейшество свободно говорит на английском языке и рекомендует буддийским монахам заниматься его изучением для международного общения.

Буддизм приобрел широкую популярность в Северной Америке благодаря активному взаимодействию азиатских буддистов и их западных последователей. Это становится очевидным, когда речь идет о разветвленной сети различных буддийских организаций, центров и фондов, призванных к поддержанию и распространению буддийского учения в разных частях Америки. Например, Д. Морреал (D. Morreale) в своей книге «Буддийская Америка: центры, ретриты, практики» попытался охватить практически все американские буддийские храмы, организации и центры, перечисление которых занимает 350 страниц.

Научный интерес к буддизму, начавшийся открытым диалогом на Всемирном Парламенте Религий в Чикаго в 1893 г., продолжает развиваться и в настоящее время. Тогда на форуме впервые выступили буддисты и объявили о том, что буддизм есть философия и вполне согласуется с современной наукой, а сегодня буддийские философы и ученые в сотрудничестве с западными представителями науки активно создают исследовательские институты и лаборатории, академические учреждения для изучения буддийского наследия. 
Свобода совести и вероисповедания в Северной Америке позволяет процветать буддизму как религиозной вере миллионам потомков китайцев, японцев, корейцев и вьетнамцев, массово иммигрировавших в США в XIX в. Важной характеристикой распространения и адаптации буддизма Махаяны в Северной Америке являются иммиграция тибетских монахов после трагических событий в Тибете, активизация деятельности тибетских учителей и поддержка тибетских беженцев западными странами. Наибольшее распространение буддизма Махаяны в Америке и на Западе связано с просветительской деятельностью Его Святейшества Далай-ламы XIV и его сотрудничеством с научным и академическим сообществом США.

Миротворческий посыл буддийского учения представляется наиболее актуальным в современное время, что является одним из основных факторов возрастающего интереса к нему в западном мире. Близкое и всестороннее знакомство западной культуры с буддизмом, начавшееся в середине XIX в., переросло в стабильный процесс взаимодействия и взаимопроникновения в разных формах и на разных уровнях. Философское наследие буддизма Махаяны настолько велико и разнообразно, что, кажется, невозможно объять и воспринять все его аспекты. Однако традиция просветления обнаружила, что нет барьера для совершенного постижения природы реальности. Не существует жесткой структуры вещей, не существует абсолютно фиксированного порядка, который заставил бы их вечно следовать одним путем и никогда не позволял бы следовать другим. Такое мировоззрение оказалось настолько притягательным для западной публики, что она начала эксперименты для реализации и подтверждения буддийских ценностей в надежде обрести счастливое состояние ума, не подвластное ни времени, ни пространству.

\section{Литература}

Далай-лама XIV. Гарвардские лекции. 1981. [Электронный ресурс]. Режим доступа: http://www.theosophy.ru/lib/dl-harv.htm. (дата обращения: 27.11.15).

Крэнстон, С.Е.П.Б: Необыкновенная жизнь и влияние Елены Блаватской, основательницы современного теософического движения - [Электронный pecypc]. - Режим доступа: http://www.theosophy.ru/lib/wl-the02.htm.

Batchelor, S. Buddhism without beliefs. - New York: Riverhead Books, 1997.

Blavatsky, H. The Voice of the Silence. With the Foreword by the XIVth Dalai Lama. - Concord Grove Press, 1989. 
Cuong Tu Nguyen \& A.W. Barber. "Vietnamese Buddhism in North America: Tradition and Acculturation". In: Charles S. Prebish and Kenneth K. Tanaka (eds). The Faces of Buddhism in America. - Berkeley: University of California Press, 1998. $-130 \mathrm{p}$.

Geshe Wangyal. The Door of Liberation: Essential Teachings of the Tibetan Buddhist Tradition. - Boston: Wisdom Publications, 1995. - $301 \mathrm{c}$.

Nattier, Jan. "Who is a Buddhist? Charting the Landscape of Buddhist America". In: Prebish and Tanaka (eds.). Faces of Buddhism in America. - 1998. P. 183-195.

Nattier, Jan. "American Buddhists: who are they?" In: Current, No.395 (Sep 1997) - P. 6-10.

Prebish Charles S., Tanaka Kenneth K. The Faces of Buddhism in America. Berkeley and Los Angeles: University of California Press, 1998. vIII, $370 \mathrm{pp}$.

Prebish, Charles. Luminous passage: the practice and study of Buddhism in America. - Berkley, CA: University of California Press, 1999. - 345 p.

Richard P. Taylor. Blavatsky and Buddhism, Group in Buddhist Studies. - UC Berkeley, 1999. $-263 \mathrm{p}$.

Tweed, Thomas. The American Encounter with Buddhism 1844-1912: Victorian Culture and the Limits of Dissent. - Bloomington: Indiana University Press, 1992.

Seager, Richard H. Buddhism in America, Columbia Contemporary American Religion Series. - New York: Columbia University Press, 1999. - 384 p.

Show, Miranda. Passionate enlightenment women in tantric Buddhism. - New Jersey: Princeton University Press, 1994. - 291 p.

Suzuki D. T. The Field of Zen. - L.: Buddhist Society, 1969. - 105 p.

The Dalai Lama as Professor. [Электронный ресурс]. - Режим доступа: //http://dalailama.emory.edu/about/professor.html (дата обращения: 27.11.2016).

Thich Nhat Hanh. Being Peace. - Berkeley: Parallax Press, 1987. - 120 p.

Thich Nhat Hanh. Peace in every step. - New York: Bantam Books, 1991. $91 \mathrm{p}$. 